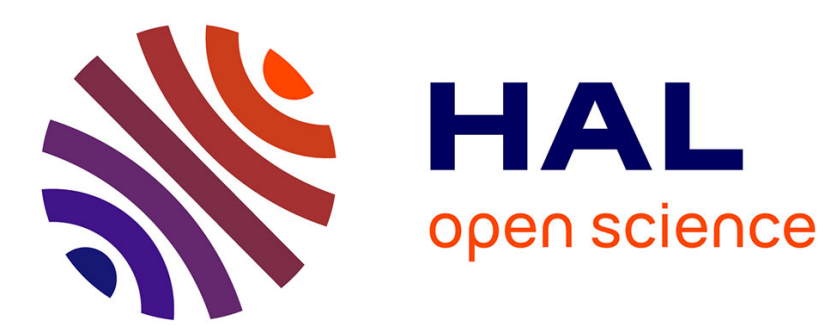

\title{
Planktonic larvae do not ensure gene flow in the edible sea urchin Paracentrotus lividus
}

\author{
Gwilherm Penant, D. Aurelle, Jean-Pierre Feral, Anne Chenuil
}

\section{To cite this version:}

Gwilherm Penant, D. Aurelle, Jean-Pierre Feral, Anne Chenuil. Planktonic larvae do not ensure gene flow in the edible sea urchin Paracentrotus lividus. Marine Ecology Progress Series, 2013, 480, pp.155-170. 10.3354/meps10194 . hal-01631351

\section{HAL Id: hal-01631351 \\ https://hal.science/hal-01631351}

Submitted on 24 Aug 2019

HAL is a multi-disciplinary open access archive for the deposit and dissemination of scientific research documents, whether they are published or not. The documents may come from teaching and research institutions in France or abroad, or from public or private research centers.
L'archive ouverte pluridisciplinaire HAL, est destinée au dépôt et à la diffusion de documents scientifiques de niveau recherche, publiés ou non, émanant des établissements d'enseignement et de recherche français ou étrangers, des laboratoires publics ou privés. 


\title{
Planktonic larvae do not ensure gene flow in the edible sea urchin Paracentrotus lividus
}

\author{
Gwilherm Penant, Didier Aurelle, Jean-Pierre Feral, Anne Chenuil*
}

Aix-Marseille Université, CNRS, UMR 7263 IMBE, 13007, Marseille, France

\begin{abstract}
Previous studies of the commercially harvested sea urchin Paracentrotus lividus revealed genetic differentiation between the Atlantic Ocean and the Mediterranean Sea and between the Adriatic and other Mediterranean basins, and reported an absence of genetic structure within basins. These studies used mitochondrial markers. We augmented these data with new mitochondrial (COI) and nuclear (calpain exon-primed intron crossing) sequences and renalyzed them. We found within-basin and within-region differentiation with each genetic marker, providing, for this species, the first report of a significant and consistent genetic structure within regions in which no stable or identified oceanographic barriers had ever been reported. This was unexpected given the long planktonic larval phase. With the mitochondrial marker, the easternmost population from Lebanon appeared strongly differentiated from other populations, with $\Phi_{\mathrm{ST}}$ values of the same order as those between Atlantic and Mediterranean basins, and a differentiation of the same magnitude was found for the northernmost population (Galway, Ireland). Among basins, gene flow appeared unidirectional, from the Atlantic to the Mediterranean Sea, and we found an admixture area between Adriatic and other Mediterranean populations. The divergence between Atlantic and Mediterranean basins was estimated to have started between 270000 and 370000 yr ago. Chaotic genetic patchiness appears unlikely to be the single factor responsible for such a differentiation, and some environmental or hydrological factors that are relatively stable over years, are probably involved. Methodological aspects such as sample sizes and the choice of statistics $\left(F_{\mathrm{ST}}\right.$ versus $\left.\Phi_{\mathrm{ST}}\right)$ contributed to the increased detection power of our study.
\end{abstract}

KEY WORDS: Phylogeography $\cdot$ Mitochondrial DNA $\cdot$ Nuclear EPIC $\cdot$ Divergence time $\cdot$ Genetic structure $\cdot F_{\mathrm{ST}} \cdot \Phi_{\mathrm{ST}}$

\section{INTRODUCTION}

The Mediterranean Sea is a biodiversity hotspot, sheltering $6.27 \%$ of the total marine biodiversity in less than $1 \%$ of the global ocean surface. The Mediterranean Sea is subjected to high anthropogenic pressures, such as increasing human population density along the coasts, harvesting, maritime traffic, and aquaculture (Coll et al. 2010). Thus, knowledge of marine biodiversity, including intraspecific genetic diversity, is required for effective management of this environment. The marine realm was traditionally considered to be a highly dispersive environment, where genetic differentiation is lower and barriers to gene flow are less obvious than in terrestrial environments (Avise 1998). Indeed, large population sizes and free larval stages theoretically induce much lower differentiation levels than those observed for related freshwater species (Avise 2000). Nevertheless, studies of larval dispersal have highlighted the fact that pelagic larval duration may be poorly correlated with genetic structure (Weersing \& Toonen 2009), and that larvae are not simply passive particles. Population genetics studies using variable markers also reported genetic structure in highly mobile species (Ruzzante et al. 2006, Chaoui et al. 2009). 
These results agree with the observation that the marine environment is heterogeneous and composed of different water masses that do not readily mix. Relationships between water masses, which are strongly associated with differences in temperature and salinity, influence marine circulation and thus dispersal between populations. This means that the main oceanographic barriers constitute phylogeographical breaks for various species, which are often congruent with biogeographical breaks, as predicted by theory (Avise 2000). For the majority of species investigated, a discontinuity in allele frequencies is observed between the Atlantic and the western basin of the Mediterranean Sea. This break is often located at the Almeria-Oran front, about $200 \mathrm{~km}$ east of the strait of Gibraltar (Borsa et al. 1997a, Patarnello et al. 2007). The less studied transition between western and eastern basins of the Mediterranean Sea, often associated with the Siculo-Tunisian sill, also constitutes a common discontinuity in allele frequencies within the Mediterranean Sea. This was revealed by genetic analyses in macrophytes (Arnaud Haond et al. 2007), fishes (Borsa et al. 1997a, Bahri-Sfar et al. 2000), and invertebrates (Zitari-Chatti et al. 2009, Zulliger et al. 2009). A break was also reported within the Aegean Sea, as seen in fishes (Borsa et al. 1997b, Domingues et al. 2005, Magoulas et al. 2006, Zitari-Chatti et al. 2009, Zulliger et al. 2009), in a bivalve (Tarnowska et al. 2010) and in an ophiuroid species complex (Boissin et al. 2011). A discontinuity between Adriatic and Mediterranean populations was also observed in fishes (Maggio et al. 2009) and the sea urchin Paracentrotus lividus (Maltagliati et al. 2010), and is suspected in other marine invertebrates (e.g. Peijnenburg et al. 2006, Aurelle et al. 2011). Analyzing the genetic structure of marine species is important for understanding their evolution in this dispersive environment, and is also a prerequisite for fisheries management and conservation (Avise 1998).

The commercially harvested sea urchin Paracentrotus lividus is considered to be a key species of the infralittoral rocky shore of the Mediterranean Sea and northeastern Atlantic Ocean (Sala et al. 1998, Pinnegar et al. 2000, Micheli et al. 2005, Guidetti 2006). It is found from the Canary Islands and the coast of Mauritania to the western coast of Ireland in the Atlantic Ocean, and throughout the entire Mediterranean Sea. Although numerous studies have dealt with the biology and the ecology of this species (e.g. Pedrotti 1993, Lozano et al. 1995, Boudouresque \& Verlaque 2007, Sellem \& Guillou 2007), phylogeography and population genetics approaches using DNA markers are recent. The first studies on these topics were based on allozymes (Arculeo et al. 1998), random amplification of polymorphic DNA (Rizzo et al. 2009), or suggested genetic determinants for some morphological characteristics (Louise \& Benard 1993, $1995 a, b)$. However, their spatial scale and the characteristics of the markers were of limited relevance for phylogeographical inference. In P. lividus, only mitochondrial-based phylogeographic studies have evidenced discontinuities between major ocean basins (i.e. between the Mediterranean and the Atlantic: Duran et al. 2004, Calderón et al. 2008, Maltagliati et al. 2010; between the Mediterranean and the Adriatic: Maltagliati et al. 2010). Within basins, spatial genetic structure has been observed with the mitochondrial cytochrome $c$ oxidase subunit I (COI) marker along the Mediterranean Spanish coast (Calderón et al. 2012). Nevertheless, such a structure was not observed in all years and was not consistent among all populations, and this differentiation disappeared when cohorts were pooled. At a local scale, Iuri et al. (2007) did not find any genetic structure in the region of Naples, Italy. For temporal comparisons, differentiation among cohorts was demonstrated using the bindin gene (Calderón \& Turon 2010), appeared occasionally with COI (Calderón et al. 2012), and was not observed with microsatellites (Calderón et al. 2009a).

One potential limitation of previous studies could be the use of a single locus. The high stochasticity of the coalescent process makes inferences based on a single marker less reliable (Hudson \& Turelli 2003). Moreover, mitochondrial DNA, which is the most used in these cases, might be misleading because of its uniparental inheritance and the potential impact of selective effects (Galtier et al. 2009). In our study, we combined published and novel genetic data to investigate the population structure of Paracentrotus lividus at different spatial scales at several loci. Specifically, we reanalyzed the data from the 3 published large-scale phylogeographic studies (Duran et al. 2004, Calderón et al. 2008, Maltagliati et al. 2010) and combined this with new mitochondrial (COI) and nuclear (calpain exon-primed intron crossing, EPIC) datasets. Both distance-based and frequency-based metrics were used for 2 reasons: (1) in order to compare new to previous data and (2) because the frequency-based metric, which was not used in previous phylogeographic studies, appeared more appropriate to detect subtle genetic differentiation caused by relatively recent and contemporary processes, where migration-drift dominates over mutation. We did not use data from the ANT locus (Calderón et al. 2008) because of the uncertainty in the reconstruction of diploid sequence genotypes for this highly variable marker. We paid special 
attention to differentiation among populations within the previously defined major geographical groups (i.e. Atlantic basin, Mediterranean basin, and Adriatic basin), because increasing knowledge at this scale appeared essential for the protection of this exploited species. We also characterized the direction and intensity of gene flow between the main groups of populations, using a coalescence analysis of isolation with migration processes to improve our knowledge on the evolutionary history of this species.

\section{MATERIALS AND METHODS}

\section{Sampling}

Between 2007 and 2010, we collected 370 Paracentrotus lividus from 15 locations across most of the distribution range of this species (Table 1 and Fig. S1 in the Supplement at www.int-res.com/articles/suppl/ m480p155_supp.pdf). One specimen of Psammechinus miliaris was collected from the Roscoff location. All specimens were collected from depths of between 0 and $1 \mathrm{~m}$. Samples of spines or gonads were preserved in $95 \%$ ethanol.

\section{Extraction, amplification, and sequencing of DNA}

Different extraction protocols were chosen depending on available tissues. A Chelex protocol was used for DNA extraction from gonad tissue. Tissues were submerged in a $10 \%$ Chelex solution and heated at $95^{\circ} \mathrm{C}$ for $45 \mathrm{~min}$. The Wizard SV Genomic DNA purification system (Promega) was used for DNA extraction from spine samples, according to the manufacturer's instructions. DNA sequences from 3 previous studies (Duran et al. 2004, Calderón et al. 2008, Maltagliati et al. 2010) were retrieved from GenBank (See Table 1 for dataset details).

Amplifications of a 609 bp fragment of the mitochondrial COI gene were performed using the primers COIe-F and COIe-R (Arndt et al. 1996), with the following cycling conditions: $94^{\circ} \mathrm{C}$ for $2 \mathrm{~min}$, 30 cycles of $94^{\circ} \mathrm{C}$ for $30 \mathrm{~s}, 48^{\circ} \mathrm{C}$ for $15 \mathrm{~s}$, and $72^{\circ} \mathrm{C}$ for $1 \mathrm{~min}$; and a final $4 \mathrm{~min}$ elongation at $72^{\circ} \mathrm{C}$. Reactions were performed in a $25 \mu 1$ volume containing $1 \mathrm{U}$ of FlexiGo Taq polymerase (Promega), $1.5 \mathrm{mM}$ of $\mathrm{MgCl}_{2}, 200 \mu \mathrm{M}$ of dNTPs, $0.25 \mu \mathrm{M}$ of each primer, and $2.5 \mu 1$ of DNA template. Amplicons were then purified and sequenced using an ABI automated sequencer by the Genomer platform (Roscoff Marine Station Sequencing Core Facility, Roscoff, France).
Amplifications of $\sim 650 \mathrm{bp}$ fragments from calpain 7 intron i2 1 (Chenuil et al. 2010) were performed using primers specific for Paracentrotus lividus (i21-F1: 5'GAG TCA AGA GAA AGG TAT GAG C-3'; i21-R2: 5'-CGA TAC CCA GAA TTC ATT GCG G-3'). Reactions were carried out using the following cycling conditions: $94^{\circ} \mathrm{C}$ for $2 \mathrm{~min}$; 12 'touch-down' cycles of $94^{\circ} \mathrm{C}$ for $30 \mathrm{~s}$, annealing between 60 and $50^{\circ} \mathrm{C}$ with a $2^{\circ} \mathrm{C}$ decrease every 2 cycles for $15 \mathrm{~s}$, and $1 \mathrm{~min}$ at $72^{\circ} \mathrm{C}$; and a final $4 \mathrm{~min}$ elongation at $72^{\circ} \mathrm{C}$. Reactions were performed in a $25 \mu$ volume containing $1 \mathrm{U}$ of FlexiGo Taq polymerase (Promega), $2 \mathrm{mM}$ of $\mathrm{MgCl}_{2}$, $200 \mu \mathrm{M}$ of dNTPs, $0.25 \mu \mathrm{M}$ of each primer, and $2.5 \mu \mathrm{l}$ of DNA template.

\section{Cloning of i21 amplicons}

The i21 marker PCR products were cloned into pGEM-T easy (Promega) following the manufacturer's instructions. Four clones for each individual were sequenced by AGOWA, Germany. Direct sequencing from PCR products was performed to check for homozygosity when 4 identical clones were retrieved. For confirmed homozygotes, 2 identical sequences were retained in the dataset for further analysis. For heterozygotes, the 2 different sequences were retained in the dataset. In rare cases, more than 2 different sequences were obtained for the same individual, and it was always due to the appearance of singletons, which were removed.

\section{Data analysis}

The COI dataset produced in the present study was analyzed along with the COI dataset retrieved from Duran et al. (2004). The 3 other datasets (i21, this study; 16S, Calderón et al. 2008; cytochrome $b$ [Cyt b], Maltagliati et al. 2010) were analyzed separately. For the i2 1 intron, a fragment of 200 to $250 \mathrm{bp}$, including a poly-A sequence, was rejected because of a potential error introduced by PCR, cloning, or sequencing. Two fragments of the i2 1 marker were used for further analyses; a 110 bp coding fragment (exon; without indel) and a non-coding fragment (intron) of 300 to $310 \mathrm{bp}$. Insertion/deletion positions in this second fragment were re-coded using the simple gap coding algorithm implemented in SeqState (Muller 2005), resulting in a $310 \mathrm{bp}$ alignment.

Haplotype diversity (Hd) and nucleotide diversity $(\pi)$ were computed for each marker using DNAsp version 5.1 (Librado \& Rozas 2009). A rarefaction 
Table 1. Paracentrotus lividus. Location of sampling sites and number of individual samples per marker. -: Unavailable data. Superscripts indicate data sources: ${ }^{a}$ this study, ${ }^{b}$ Duran et al. (2004), ${ }^{\mathrm{c} C a l d e r o ́ n ~ e t ~ a l . ~(2008), ~}{ }^{\mathrm{d} M a l t a g l i a t i ~ e t ~ a l . ~(2010) . ~ C o l l e c-~}$ tion years of the new data are given next to the population name. Codes are the same as in Fig. S1 in the Supplement at www.int-res.com/articles/suppl/m480p155_supp.pdf

\begin{tabular}{|c|c|c|c|c|c|c|c|}
\hline Code & Population & $\mathrm{COI}^{\mathrm{a}}$ & $\mathrm{COI}^{\mathrm{b}}$ & $\mathrm{i} 21^{\mathrm{a}}$ & $16 \mathrm{~S}^{\mathrm{c}}$ & Cyt bd & Region \\
\hline 1 & Galway & - & - & - & - & 10 & Atlantic \\
\hline 2 & Roscoff(2007) & 25 & 10 & 13 & 9 & 10 & Atlantic \\
\hline 3 & Santander & - & 11 & - & 10 & - & Atlantic \\
\hline 4 & Ferrol (2007) & 20 & 11 & 14 & 10 & - & Atlantic \\
\hline 5 & Baiona & - & - & - & - & 10 & Atlantic \\
\hline 6 & Cascais / Lisbon & - & 11 & - & 11 & - & Atlantic \\
\hline 7 & Mosteiros & - & - & - & - & 10 & Atlantic \\
\hline 8 & Tenerife & - & 11 & - & 8 & - & Atlantic \\
\hline 9 & Morocco (2008) & 26 & - & 14 & - & - & Atlantic \\
\hline 10 & Cadiz & - & - & - & 11 & - & Atlantic \\
\hline 11 & Tarifa & - & 11 & - & 10 & - & Gibraltar \\
\hline 12 & Ceuta & - & - & - & 10 & - & Gibraltar \\
\hline 13 & La Herradura & - & 9 & - & - & - & Alboran Sea \\
\hline 14 & Cabo de Gata & - & 10 & - & 10 & - & Western Mediterranean \\
\hline 15 & Cabo de Palos & - & 10 & - & - & - & Western Mediterranean \\
\hline 16 & Nao & - & - & - & 7 & - & Western Mediterranean \\
\hline 17 & Valencia (2010) & 21 & - & 15 & - & - & Western Mediter ranean \\
\hline 18 & Eivissa & - & 11 & - & - & - & Western Mediterranean \\
\hline 19 & Cabrera & - & - & - & 9 & - & Western Mediterranean \\
\hline 20 & Columbretes & - & - & - & 12 & - & Western Mediterranean \\
\hline 21 & Blanes & - & 12 & - & - & - & Western Mediterranean \\
\hline 22 & Tossa de Mare & - & - & - & 13 & - & Western Mediterranean \\
\hline 23 & Palamos & - & - & - & - & 10 & Western Mediterranean \\
\hline 24 & Medes & - & 10 & - & - & 10 & Western Mediterranean \\
\hline 25 & Cadaques & - & - & - & 8 & - & Western Mediterranean \\
\hline 26 & Carro (2010) & 15 & - & - & - & - & Western Mediterranean \\
\hline 27 & Marseille (2010) & 34 & - & 12 & - & - & Western Mediterranean \\
\hline 28 & Porquerolles (2010) & 27 & - & - & - & - & Western Mediterranean \\
\hline 29 & Saint-Raphaël (2010) & 29 & - & - & - & - & Western Mediterranean \\
\hline 30 & Villefranche / Mer (2010) & 25 & - & - & - & - & Western Mediterranean \\
\hline 31 & Corsica $(2010)$ & 39 & - & 13 & 8 & - & Western Mediterranean \\
\hline 32 & Quercianella & - & - & - & - & 10 & Western Mediterranean \\
\hline 33 & Pittulongu & - & - & - & - & 10 & Western Mediterranean \\
\hline 34 & Alghero & - & - & - & - & 10 & Western Mediterranean \\
\hline 35 & Costa degli Dei & - & - & - & - & 10 & Western Mediterranean \\
\hline 36 & Ustica & - & - & - & - & 10 & Western Mediterranean \\
\hline 37 & Annaba (2008) & 19 & - & 15 & - & - & Western Mediterranean \\
\hline 38 & Tunis & - & - & - & - & 10 & Western Mediterranean \\
\hline 39 & Marsaskala & - & - & - & - & 10 & Eastern Mediterranean \\
\hline 40 & Siracusa & - & - & - & - & 10 & Eastern Mediterranean \\
\hline 41 & Giardini Naxos & - & - & - & - & 10 & Eastern Mediterranean \\
\hline 42 & Santa Catarina di Nardo & - & - & - & - & 10 & Eastern Mediterranean \\
\hline 43 & Brindisi & - & - & - & - & 10 & Adriatic \\
\hline 44 & Manfredonia & - & - & - & - & 10 & Adriatic \\
\hline 45 & Lesina & - & - & - & - & 10 & Adriatic \\
\hline 46 & Termoli (2007) & 16 & - & 15 & - & - & Adriatic \\
\hline 47 & Ancona & - & - & - & - & 10 & Adriatic \\
\hline 48 & Mljet & - & - & - & - & 10 & Adriatic \\
\hline 49 & Miramare & - & - & - & - & 10 & Adriatic \\
\hline 50 & Iraklion (2009) & 29 & - & 14 & - & 10 & Eastern Mediterranean \\
\hline 51 & Matala (2009) & 20 & - & 15 & - & - & Eastern Mediterranean \\
\hline 52 & Greece & - & - & - & 12 & - & Eastern Mediterranean \\
\hline 53 & Epanomi & - & - & - & - & 10 & Eastern Mediterranean \\
\hline 54 & Rhodes & - & - & - & - & 10 & Eastern Mediterranean \\
\hline 55 & Kyrenia & - & - & - & - & 10 & Eastern Mediterranean \\
\hline 56 & Lebanon (2008) & 25 & - & 14 & - & - & Eastern Mediterranean \\
\hline
\end{tabular}


analysis was performed for allelic richness in COI using the Contrib software (Petit et al. 1998) to estimate the potential effects of differences in sample sizes between sites. This analysis was not performed for the other markers because sample sizes were homogeneous.

Haplotype networks based on the most parsimonious connections of haplotypes at the 95\% probability level were reconstructed using the program TCS 1.21 (Clement et al. 2000). Based on these networks, we defined haplogroups for COI, Cyt b, and i2 1 . Haplogroups could not be defined for the $16 \mathrm{~S}$ marker, because of the low level of polymorphism. Haplogroup frequencies per population were then recorded on geographical maps.

Selective neutrality tests were used to test for departure from mutation-drift equilibrium due to changes in effective size or selective effects. We used Fu's Fs test (Fu 1997), Tajima's $D$ test (Tajima 1989), and Ramos-Onsins and Rozas' $R^{2}$ test (Ramos- Onsins $\&$ Rozas 2002) implemented in DNAsp 5.1 (Librado $\&$ Rozas 2009). Significance levels were calculated using 10000 coalescent simulations with- out recombination.

Among-population differentiations were estimated by the $\theta$ estimator of $F_{\mathrm{ST}}$ (Weir \& Cockerham 1984) and the $\Phi_{\text {ST }}$ statistics using the proportion of differences between haplotypes (Excoffier et al. 1992). These parameters were calculated using ARLEQUIN version 3.5 (Excoffier \& Lischer 2010). The null hypothesis of no differentiation was tested by performing 10000 permutations among individuals between populations. The Benjamini and Hochberg correction (Benjamini \& Hochberg 1995) for multiple tests was applied to the p-values calculated for the $F$ statistics. ARLEQUIN was used to study the hierarchical population structure for each molecular marker, with an analysis of molecular variance (AMOVA) based on haplotype frequencies. Different hypotheses on the position of the transition between the Atlantic and the Mediterranean basins, and following an east-west transect, were tested for the COI and the 16S markers, but not for Cyt b and i2 1 markers. The density of sampled sites around this transition zone was too weak to perform such an analysis. Different hypotheses on the position of the transition between the Adriatic and the Mediterranean basins were tested for the Cyt b marker, which displayed a sufficient density of samples in this area (see Fig. 2, and Tables S8 to S10 in the Supplement for details). Isolation by distance (IBD) was studied at different scales using the correlation between $F_{\mathrm{ST}} /\left(1-F_{\mathrm{ST}}\right)$ as the genetic distance (i.e. based on haplotype fre- quencies) and the logarithm of shoreline distance between sampled sites following the sea current direction as the geographic distance. The correlation was tested using a Mantel test based on 10000 permutations realized with the Genepop software (Raymond \& Rousset 1995).

To estimate demographic parameters using the IMa2 software (Nielsen \& Wakeley 2001), we first had to estimate the rate of sequence evolution for the markers used. Previous studies on Paracentrotus lividus used a range of nucleotide sequence divergence, consisting of 1.6 to $3.5 \% \mathrm{Myr}^{-1}$ for the COI marker (Lessios et al. 1999, McCartney et al. 2000). Because of the high variability in the evolutionary rate reported for some sea urchins (Chenuil et al. 2008), we attempted to calibrate the COI molecular clock. Data for the coding fragment of the i2 1 marker were not available in the literature, but we obtained sequences for the same fragment from Strongylocentrotus purpuratus and Psammechinus miliaris. For Cyt b, as no molecular clock references were found, we also attempted to calibrate its molecular clock with species from the genus Strongylocentrotus. The age of the most recent common ancestor for S. purpuratus and the Echinidae (to which $P$. miliaris and $P$. lividus belong) was set at $30 \mathrm{Myr}$ on the basis of paleontological records (Smith et al. 2006). The jModelTest software (Posada 2008) was used to choose the optimal model of sequence evolution. The HKY model of nucleotide substitution (Hasegawa et al. 1985) was retained, and the rate of evolution was calibrated using a Bayesian Markov chain Monte Carlo (MCMC) framework implemented in BEAST v1.61 (Drummond \& Rambaut 2007). Rates were estimated under the assumption of both strict clock and relaxed clock models. Following $5 \times 10^{5}$ steps of burn-in, posterior probabilities of parameter estimates were calculated with $5 \times 10^{6}$ cycles of data collection. Five runs were performed and combined to detect and avoid biased estimations due to MCMC chains blocked at local maxima.

The time of splitting (from a single population) between pairs of populations (or groups of populations), effective population sizes, and migration rates in both directions were estimated using IMa2 (Hey 2010). This analysis provides estimators of a split time and migration rates under an island model. A generation time of $3 \mathrm{yr}$ was used for the conversion of generation times into years (Lozano et al. 1995). Following $5 \times 10^{5}$ steps of burn-in, posterior probabilities of parameter estimates were calculated with $10 \times$ $10^{6}$ cycles of data collection. Five runs with different starting positions were performed and combined. We 
used uniform priors and 20 heated chains with the heating terms suggested by the IMa2 user's guide for small to medium size dataset and medium heating, in order to obtain high swap rates between adjacent pairs of chains.

The PowSim application (Ryman \& Palm 2006) was used to assess the influence of sample sizes on the probability of a given $F_{\text {ST }}$ value to appear significant, for a given allele frequency distribution, which was the one we obtained for the COI data set. The program simulates a population fission which occurred a given number of generations ago from a population of a given effective size, and this pair of parameters determines the resulting $F_{\mathrm{ST}}$ value between populations.

\section{RESULTS}

\section{Marker polymorphism}

Mitochondrial markers. The complete COI dataset comprised 497 sequences, with 370 new sequences and 127 previously obtained by Duran et al. (2004).
These sequences corresponded to 179 different haplotypes (Table 2). Thirty-four percent of the sequences corresponded to the 4 most common haplotypes found in western and eastern Mediterranean and Atlantic samples, and 30\% were unique sequences. The Lebanese sample did not share any haplotype with Atlantic populations. Hd was high in all populations (0.91-1.0), the highest being observed in Atlantic and Lebanese populations (Table 2). Nucleotide diversity ranged from 0.005 to 0.010 with an overall mean of 0.007 (Table 2). Rarefaction analyses did not indicate any influence of sample size differences on allelic richness. Previous studies indicated nucleotide diversity of 0.001 to 0.005 for $16 \mathrm{~S}$ and 0.003 to 0.012 for Cyt b (Calderón et al. 2008, Maltagliati et al. 2010).

Nuclear marker. The amplification and cloning of the i2 1 locus for 154 individuals from 11 populations resulted in 296 sequences and 97 alleles for the noncoding part of this locus. Similar results were obtained when considering the coding part but with less diversity and larger sample size, as we did not succeed in sequencing the non-coding part for 6 individuals (data not shown). Haplotype diversity and

Table 2. Paracentrotus lividus. Diversity measures for the studied populations. n: number of individuals; Nh: number of haplotypes; Hd: haplotype diversity; $\pi$ : nucleotide diversity; -: data unavailable. Superscripts indicate data sources: ${ }^{2}$ this study, ${ }^{\mathrm{b}}$ Duran et al. (2004). Codes are the same as in Fig. S1 in the Supplement

\begin{tabular}{|c|c|c|c|c|c|c|c|c|c|c|c|c|c|}
\hline \multirow[t]{2}{*}{ Code } & \multirow[t]{2}{*}{ Population } & \multicolumn{4}{|c|}{$-\mathrm{COI}-$} & \multicolumn{4}{|c|}{- i2 1 (coding) } & \multicolumn{4}{|c|}{ —i21 (non-coding) } \\
\hline & & $\mathrm{n}$ & $\mathrm{Nh}$ & $\mathrm{Hd}$ & $\pi$ & $\mathrm{n}$ & $\mathrm{Nh}$ & $\mathrm{Hd}$ & $\pi$ & $\mathrm{n}$ & $\mathrm{Nh}$ & $\mathrm{Hd}$ & $\pi$ \\
\hline 2 & Roscoff ${ }^{a b}$ & 35 & 19 & 0.96 & 0.008 & 13 & 13 & 0.92 & 0.042 & 12 & 16 & 0.96 & 0.056 \\
\hline 3 & Santander ${ }^{\mathrm{b}}$ & 11 & 10 & 0.98 & 0.007 & - & - & - & - & - & - & - & - \\
\hline 4 & Ferrol $^{\text {ab }}$ & 31 & 18 & 0.96 & 0.007 & 14 & 12 & 0.88 & 0.039 & 11 & 17 & 0.98 & 0.063 \\
\hline 6 & Cascais ${ }^{\mathrm{b}}$ & 11 & 7 & 0.91 & 0.006 & - & - & - & - & - & - & - & - \\
\hline 8 & Tennerife ${ }^{b}$ & 11 & 9 & 0.95 & 0.008 & - & - & - & - & - & - & - & - \\
\hline 9 & Morocco $^{a}$ & 26 & 22 & 0.99 & 0.006 & 14 & 12 & 0.92 & 0.039 & 12 & 15 & 0.96 & 0.061 \\
\hline 11 & Tarifa $^{\mathrm{b}}$ & 11 & 8 & 0.95 & 0.005 & - & - & - & - & - & - & - & - \\
\hline 13 & La Herradura ${ }^{\mathrm{b}}$ & 9 & 8 & 0.97 & 0.007 & - & - & - & - & - & - & - & - \\
\hline 14 & Cabo de Gata b & 10 & 6 & 0.84 & 0.004 & - & - & - & - & - & - & - & - \\
\hline 15 & Cabo des Palos ${ }^{b}$ & 10 & 10 & 1.00 & 0.010 & - & - & - & - & - & - & - & - \\
\hline 17 & Valencia $^{a}$ & 21 & 15 & 0.96 & 0.008 & 15 & 12 & 0.72 & 0.013 & 15 & 10 & 0.68 & 0.014 \\
\hline 18 & Eivissa $^{\mathrm{b}}$ & 11 & 10 & 0.98 & 0.007 & - & - & - & - & - & - & - & - \\
\hline 21 & Blanes $^{\mathrm{b}}$ & 12 & 8 & 0.92 & 0.005 & - & - & - & - & - & - & - & - \\
\hline 24 & Medes b & 10 & 9 & 0.98 & 0.006 & - & - & - & - & - & - & - & - \\
\hline 26 & Carro $^{a}$ & 15 & 9 & 0.91 & 0.009 & - & - & - & - & - & - & - & - \\
\hline 27 & Marseille $^{a}$ & 34 & 20 & 0.92 & 0.006 & 12 & 9 & 0.66 & 0.018 & 12 & 11 & 0.82 & 0.015 \\
\hline 28 & Porquerolles $^{a}$ & 27 & 17 & 0.96 & 0.007 & - & - & - & - & - & - & - & - \\
\hline 29 & Saint-Raphaël ${ }^{a}$ & 29 & 19 & 0.92 & 0.007 & - & - & - & - & - & - & - & - \\
\hline 30 & Villefranche / Mer ${ }^{a}$ & 25 & 15 & 0.91 & 0.008 & - & - & - & - & - & - & - & - \\
\hline 31 & Corsica $^{a}$ & 39 & 25 & 0.96 & 0.007 & 13 & 13 & 0.79 & 0.024 & 13 & 15 & 0.90 & 0.037 \\
\hline 37 & Annaba $^{a}$ & 19 & 15 & 0.97 & 0.007 & 15 & 6 & 0.58 & 0.017 & 15 & 17 & 0.84 & 0.027 \\
\hline 46 & Termoli a & 16 & 11 & 0.91 & 0.006 & 15 & 10 & 0.56 & 0.014 & 15 & 10 & 0.71 & 0.015 \\
\hline 50 & Iraklion $^{a}$ & 29 & 19 & 0.92 & 0.006 & 14 & 12 & 0.73 & 0.022 & 15 & 13 & 0.85 & 0.031 \\
\hline 51 & Matala $^{a}$ & 20 & 15 & 0.96 & 0.005 & 15 & 9 & 0.47 & 0.010 & 14 & 13 & 0.75 & 0.015 \\
\hline 56 & Lebanon $^{a}$ & 25 & 20 & 0.98 & 0.009 & 14 & 9 & 0.67 & 0.019 & 14 & 14 & 0.78 & 0.028 \\
\hline Total & & 497 & 179 & 0.96 & 0.007 & 154 & 73 & 0.80 & 0.027 & 148 & 97 & 0.88 & 0.035 \\
\hline
\end{tabular}


nucleotide diversity appeared to be higher for the Atlantic populations than for the Mediterranean ones (Table 2). One i2 1 allele was found only in the Mediterranean basin, where its frequency reached $\sim 30 \%$ of all alleles. Atlantic and Mediterranean populations only shared 4 alleles for this marker.
Statistical parsimony network and haplogroup mapping. The haplotype networks for COI and i21 were characterized by the presence of star-like patterns centered on the most frequent haplotypes (Fig. 1). The Cyt b haplotype network displayed a higher level of polymorphism than COI and i21, and
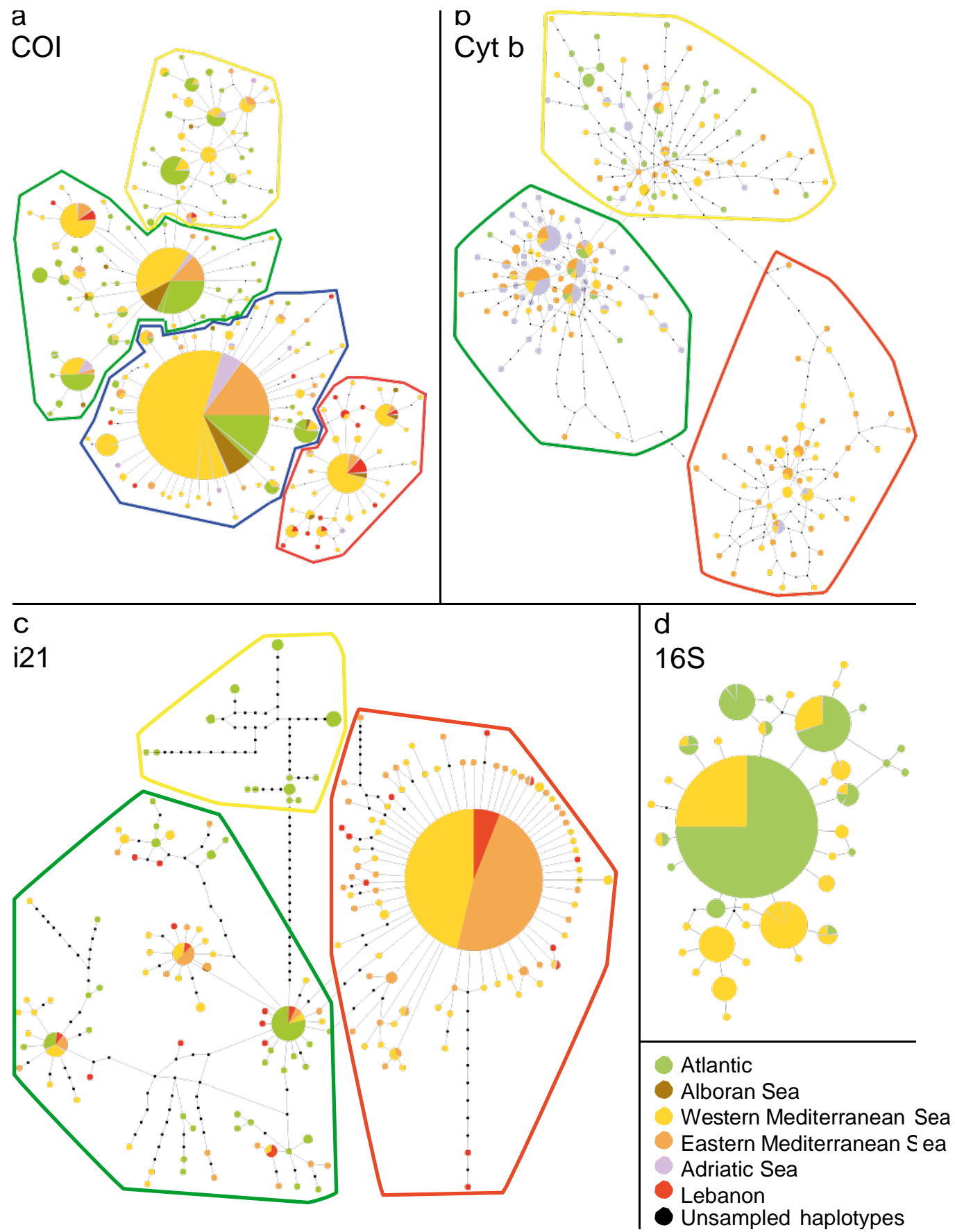

Fig. 1. Paracentrotus lividus. Statistical parsimony networks of haplotype relationships for (a) COI, (b) Cyt b, (c) the non-coding fragment of the nuclear intron i21, and (d) 16S. Each branch represents 1 mutation between the 2 adjacent sequences and black circles represent unsampled haplotypes. Circle sizes for each network are proportional to the number of individuals. Yellow, green, blue, and red polygons enclose the different haplogroups used for mapping in Fig. 2 

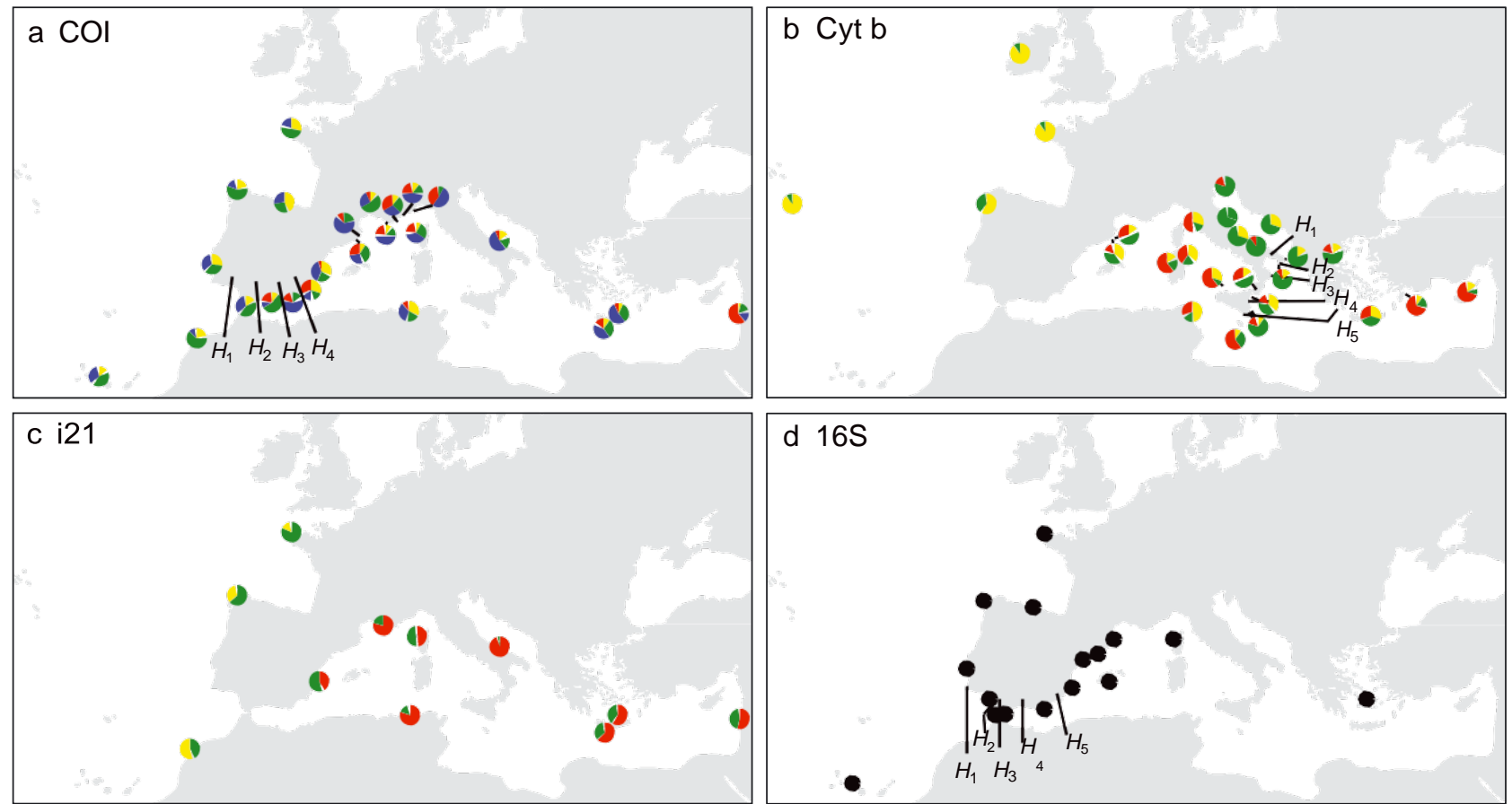

Fig. 2. Paracentrotus lividus. Mapping of haplogroups based on statistical parsimony network reconstruction for (a) COI, (b) Cyt b, and (c) i21. Pie chart colors (same as for Fig. 1 polygons) correspond to haplogroup frequencies per sampled site. Hypotheses tested by AMOVAs (see Table 3 ) are given as $H_{\mathrm{x}}$ for the 3 previously cited markers and (d) $16 \mathrm{~S}$

consisted of 3 major haplogroups (Fig. 1). For each of these 3 markers, 1 group of haplotypes was absent from Atlantic samples. This group represented half of all Mediterranean sequences for i2 1 (red group in Figs. 1 \& 2). This Mediterranean haplogroup was dominant in eastern Mediterranean samples, where it reached its maximum frequency. A second group comprised COI and Cyt b haplotypes mostly from Atlantic samples, as well as i2 1 haplotypes unique to Atlantic specimens (yellow group in Figs. 1 \& 2). For Cyt b and i2 1 markers, a third group contained haplotypes shared between all regions (green group in
Figs. 1 \& 2). A shared haplogroup for COI corresponded to 2 subgroups around 2 main haplotypes, 1 with a majority of unique haplotypes from Atlantic samples (green group in Figs. 1 \& 2), and a second mainly comprised of unique haplotypes from Mediterranean samples.

\section{Population differentiation}

Pairwise population comparisons based on $F_{\mathrm{ST}}$ were significant for most tests using the mitochondr-

Table 3. Paracentrotus lividus. AMOVA results between 2 different transition zones: between the Atlantic (ATL) and Mediterranean (MED) basins (COI and 16S) and between the Adriatic (ADR) and Mediterranean basins (Cyt b). Only hypotheses that maximized differentiation between groups and minimized differentiation within groups are presented. All hypotheses tested are presented in Tables S8 to S10 in the Supplement. $F_{\mathrm{SC}}$ : fixation index within groups (p-values in parentheses); $F_{\mathrm{CT}}$ : fixation index among groups ( $\mathrm{p}$-values in parentheses)

\begin{tabular}{|c|c|c|c|c|c|c|}
\hline \multirow[t]{2}{*}{ Transition } & \multirow[t]{2}{*}{ Marker } & \multirow{2}{*}{$\begin{array}{c}\text { Transition position } \\
\text { hypothesis }\end{array}$} & \multicolumn{2}{|c|}{ Within groups } & \multicolumn{2}{|c|}{ Among groups } \\
\hline & & & $F_{\mathrm{SC}}$ & $\%$ of variation & $F_{\mathrm{CT}}$ & $\%$ of variation \\
\hline \multirow[t]{2}{*}{ ATL / MED } & $\mathrm{COI}$ & $H_{2 \text { COI }}$ & $0.028(<0.001)$ & 2.65 & $0.059(<0.001)$ & 5.92 \\
\hline & $16 \mathrm{~S}$ & $H_{416 \mathrm{~s}}$ & $0.006(0.337)$ & 0.54 & $0.135(<0.001)$ & 13.54 \\
\hline \multirow[t]{3}{*}{ ADR / MED } & Cyt b & $H_{3 \text { cytb }}$ & $0.034(<0.05)$ & 2.86 & $0.159(<0.001)$ & 15.88 \\
\hline & & $H_{4 \text { cytb }}$ & $0.033(<0.05)$ & 2.81 & $0.152(<0.001)$ & 15.18 \\
\hline & & $H_{5 \text { cytb }}$ & $0.025(0.073)$ & 2.12 & $0.159(<0.001)$ & 15.89 \\
\hline
\end{tabular}


ial markers (Tables S1 to S3 in the Supplement). The few non-significant $F_{\text {ST }}$ values for Cyt b were among Adriatic samples. For the non-coding region of i21, all pairwise $F_{\mathrm{ST}}$ values were significant, except among Atlantic populations (Table S4). The $F_{\text {ST }}$ between Atlantic and Mediterranean Sea populations was the only significant comparison for the coding region of $i 21$.

Pairwise $\Phi_{\mathrm{ST}}$ for COI showed significant differentiation between Atlantic and Mediterranean populations and between the Lebanese and other populations. The highest values were found between Lebanese and other populations. For the Cyt b marker, significant pairwise $\Phi_{\mathrm{ST}}$ values were observed between Atlantic and Mediterranean populations, between Adriatic and Mediterranean populations, and between the northernmost population of Galway, Ireland, and all other populations. Pairwise $\Phi_{\text {ST }}$ for intron i21 showed significant differentiation only between Atlantic and Mediterranean populations. Details of the values are given in Supplementary materials (Tables S1 to S4).

AMOVA on the COI marker showed a maximum differentiation between groups and a minimum differentiation within groups when the transition between Atlantic and Mediterranean Sea was set between Tarifa and La Herradura, Spain (hypothesis $\mathrm{H}_{2}$ in Fig. $2 \mathrm{a} ; F_{\mathrm{CT}}=0.059$, Table 3 ; for exact site locations, see Fig. $\mathrm{S} 1$ in the Supplement). AMOVA on the $16 \mathrm{~S}$ marker showed a maximum differentiation between groups and a minimum differentiation within groups when setting the transition between Atlantic and Mediterranean Sea between Ceuta and Cabo de Gata, Spain (hypothesis $H_{4}$ in Fig. 2d; $F_{\mathrm{CT}}=0.135$, Table 3). AMOVA on the Cyt $b$ marker revealed a maximum differentiation between groups and a minimum differentiation within groups for different hypotheses when setting the transition between groups between Brindisi and Giardini Naxos, Italy (hypotheses $H_{3}$ to $H_{5}$ in Fig. 2c; $F_{\mathrm{CT}}=0.152-0.159$, Table 3). Details of the alternate hypotheses are given in Tables $\mathrm{S} 8$ to $\mathrm{S} 10$.
The $F_{\mathrm{ST}} /\left(1-F_{\mathrm{ST}}\right)$ values for mitochondrial COI were positively correlated with the geographical distance over the whole sample range (Mantel test $r=0.3617$, $\mathrm{p}=0.017$ ) and within the western basin of the Mediterranean Sea (Mantel test $r=0.657, \mathrm{p}=0.009$ ). The nuclear genetic distance for i2 $1, F_{\mathrm{ST}} /\left(1-F_{\mathrm{ST}}\right)$, was significantly positively correlated with geographical distance over the whole sample range (Mantel test $r=0.644, \mathrm{p}=0.002)$, but not at other scales. Intrabasin pairwise comparisons $F_{\mathrm{ST}} /\left(1-F_{\mathrm{ST}}\right)$ were lower than inter-basin pairwise comparisons, independent of geographic distance.

\section{Demographic and selective neutrality tests}

Mitochondrial markers. For COI, we obtained significant values from Fu's Fs test for the majority of samples. Results of the $R^{2}$ test partially supported these results (4 out of 9 Atlantic samples and 6 out of 17 Mediterranean samples showing non-significant p-values). Tajima's $D$ test was significant for 1 sample from the Atlantic, 5 from the Mediterranean Sea, and 1 from the Adriatic Sea. For 16S, we obtained significant values from Fu's Fs test for 1 of the 8 Atlantic samples and 6 out of 8 Mediterranean samples. Results of the $R^{2}$ test supported Fu's test results for the Atlantic sample and for 3 Mediterranean samples. Tajima's $D$ test was significant for 2 Atlantic samples and 1 Mediterranean sample. For Cyt b, we obtained significant values from Fu's Fs test for 1 out of 4 Atlantic samples, 10 out of 16 Mediterranean samples, and 4 out of 6 Adriatic samples. Results of the $R^{2}$ test partially confirmed these results for Atlantic and Adriatic samples. Tajima's $D$ test was significant for a single Adriatic sample. For all 3 markers, pooling samples by basin resulted in significant values for all tests (Tables S5 to S7).

Nuclear marker. We obtained significant values for the 3 tests for Mediterranean and Adriatic samples, but never for the Atlantic samples. All tests were significant when samples were pooled by basin.

Table 4. Paracentrotus lividus. Results of the estimation of parameters of the isolation with migration model (IMa2) at the interbasin level between Atlantic (ATL) and Mediterranean (MED) populations, according to different evolution rates for the COI marker. to: Splitting time from an ancestral population in million years; Ne: effective population sizes in millions of individuals; 2NM: population migration rate in number of gene copies per generation. Confidence intervals are in parentheses

\begin{tabular}{|c|c|c|c|c|c|c|}
\hline $\begin{array}{l}\text { COI sub. } \\
\text { rate (\%) }\end{array}$ & $t_{0}$ & Ne ATL & Ne MED & $\begin{array}{l}\text { Ne ancestral } \\
\text { population }\end{array}$ & $2 \mathrm{NM}_{\mathrm{ATL} \rightarrow \mathrm{MED}}$ & $2 \mathrm{NM}_{\mathrm{MED} \rightarrow \mathrm{ATL}}$ \\
\hline 0.49 & $0.37(0.11-0.22)$ & $1.24(0.60-2.20)$ & $11.9(8.20-28.00)$ & $0.54(0.20-1.00)$ & $31.17(17.11-50.02)$ & $0.01(0.00-10.59)$ \\
\hline 1.60 & $0.27(0.22-0.34)$ & $2.05(1.41-2.77)$ & $3.95(2.61-5.34)$ & $0.29(0.15-0.60)$ & $31.17(17.11-50.02)$ & $0.01(0.00-10.59)$ \\
\hline
\end{tabular}




\section{Demographic parameter estimates}

The results obtained with the strict clock and relaxed clock models were similar. Therefore, the COI marker, the Cyt b marker, and the exon fragment of the i21 marker were considered to follow a strict clock model. The nucleotide sequence divergence rate was estimated to be $0.98 \% \mathrm{Myr}^{-1}$ (95\% highest posterior density, HPD: 0.62-1.42\% $\mathrm{Myr}^{-1}$ ) for COI, 1.64\% $\mathrm{Myr}^{-1}$ (95\% HPD: 1.14-2.39\% $\mathrm{Myr}^{-1}$ ) for Cyt b, and $0.72 \% \mathrm{Myr}^{-1}$ (95\% HPD: 0.38-1.10\% $\mathrm{Myr}^{-1}$ ) for the exon fragment of 121 .

Results based on a single marker led to poor precision in parameter estimation or even failed to estimate parameters for the Cyt b marker (Table S11). We estimated that the mean splitting times based on a dataset comprising all available markers (COI, 16S, Cyt b, and $\mathrm{i} 21_{\text {exon }}$ ) ranged from 0.27 to $0.37 \mathrm{Myr}$ according to the substitution rate used for the COI marker (0.49 and $1.60 \% \mathrm{Myr}^{-1}$, respectively). Gene flow appeared asymmetric, actually unidirectional, with about 30 gene copies per generation from the Atlantic Ocean to the Mediterranean Sea, and not significantly different from 0 in the reverse direction. Details and confidence intervals are given in Table 4.

Gene flow also appeared asymmetric and higher from Lebanon to the other Mediterranean populations, with about 60 gene copies per generation, and did not appear different from 0 between Lebanon and the Atlantic populations, based on a dataset comprising sequences from COI and the i2 1 exon.

\section{Influence of sample size}

The PowSim results confirmed that sample sizes used in previous studies for the COI marker had poor chances of detecting significant differentiation: between 25\% (with a chi-squared test) and 52\% (with Fisher's exact test) of $F_{\text {ST }}$ values appeared significant when sample sizes equaled 12, the maximum size used by Duran et al. (2004), whereas more than 95\% of $F_{\mathrm{ST}}$ values were significant when sample size reached 30 individuals.

\section{DISCUSSION}

\section{Intra-basin genetic structure}

Our results provide a new perspective on the genetic structure among Paracentrotus lividus populations. While previous studies based on mitochon- drial markers and $\Phi_{\mathrm{ST}}$ statistics highlighted differentiation between basins, namely the AtlanticMediterranean transition (Duran et al. 2004, Calderón et al. 2008, Maltagliati et al. 2010) and the Adriatic-Mediterranean transition (Maltagliati et al. 2010), our study reveals significant genetic differentiation at a much more local scale. The statistic used ( $\Phi_{\mathrm{ST}}$ instead of $F_{\mathrm{ST}}$ in our case) and the low number of individuals within population samples probably account for the failure of previous studies to detect the differentiation within basins and within regions that our results unambiguously established. The lower polymorphism of the $16 \mathrm{~S}$ marker may also explain previous results based on this marker.

Intra-basin $F_{\text {ST }}$ revealed significant differentiation between nearly all population pairs within the Mediterranean and Adriatic basins, some of which were geographically close (about 40 to $60 \mathrm{~km}$ between our populations from the French Mediterranean coast). Non-significant $F_{\mathrm{ST}}$ values for the COI markers were obtained only for populations retrieved from Duran et al. (2004), which presented the smallest sample size for this marker $(9<\mathrm{N}<12)$. We believe that these small sample sizes prevented the detection of regional genetic structure (Ryman et al. 2006) as supported by our simulation results. Discrepancy between $\Phi_{\mathrm{ST}}$ and $F_{\mathrm{ST}}$ can be explained by the nature of those statistics. While the $\Phi_{\mathrm{ST}}$ statistic is strongly dependent on the accumulation of mutations between the observed haplotypes, the $F_{\text {ST }}$ statistic is only dependent on the haplotype frequency distribution, because it does not consider the distances among haplotypes. Significant $F_{\mathrm{ST}}$ might thus be observed after relatively few generations of genetic drift, while significant $\Phi_{\mathrm{ST}}$ will be observed after the appearance of some mutant haplotypes. $F_{\mathrm{ST}}$ is, however, expected to be more powerful than $\Phi_{\mathrm{ST}}$ to detect significant differentiation, when allele diver- gence does not contain any relevant information since it gives an equal weight to all alleles and since the $F_{\text {ST }}$ statistics have a lower variance than the $\Phi_{\mathrm{ST}}$. However, the regional genetic differentiation revealed in this study was unexpected for a species dispersing via a planktotrophic larval stage lasting about 1 mo (Pedrotti 1993, Lozano et al. 1995). The characteristics of the reproductive biology of various marine invertebrates (e.g. variance in reproductive success, stochastic nature of larval connectivity, temporal fluctuations in selection pressures) may generate spatial or spatio-temporal patterns of genetic structure (Johnson \& Black 1984, Siegel et al. 2008). This is often called 'chaotic genetic patchiness' and refers to patterns of genetic structure which are not 
stable in time, because they are caused by neither stable oceanographic or physical barriers, nor by distance. In Paracentrotus lividus, cases of differentiation were observed among cohorts in locations of the Iberian coast but not among locations when cohorts were pooled (Calderón et al. 2012), a pattern which is typical of chaotic genetic patchiness. Our results strongly suggest that a totally different mechanism also creates genetic differentiation among locations in this species for 2 reasons: (1) genetic differentiation within regions was revealed among samples composed of various cohorts, and (2) we also found a significant pattern of IBD within the Western Mediterranean basin (with the COI marker). This strongly suggests that gene flow is not only limited by fluctuating events susceptible to generate chaotic genetic patchiness, but also by distance and by environmental factors which are relatively stable in time and remain to be determined. Such factors may either affect dispersal (hydrological factors) or fitness (differential selection). It is not likely, however, that the process of isolation by distance generates genetic differentiation among the closest locations of our survey (about $40 \mathrm{~km}$ ) since they represent the smallest distances we used in the IBD test (thus they were associated with low differentiation values, since IBD appears significant, with $\mathrm{COI}$ ).

The observation of genetic differentiation within basins refutes the definition of panmictic units proposed in previous studies (Duran et al. 2004, Calderón et al. 2008). Moreover, the analysis of the gene coding for the gamete recognition protein bindin suggested a role for prezygotic processes in the temporal genetic structuring of Paracentrotus lividus, and a differential fertilization success according to the origin of the gametes in the northwestern Mediterranean Sea (Calderón et al. 2009b, Calderón $\&$ Turon 2010). This may contribute to the genetic structure shown here. Several studies investigating Atlantic and Mediterranean genetic population structure in echinoderms did not evidence differentiation within regions for species with planktotrophic or lecithotrophic larvae (Borrero-Pérez et al. 2011, So et al. 2011, Chatti et al. 2012), whereas some cases of differentiation at smaller distances have been reported for species without a dispersing larva (Baus et al. 2005, Boissin et al. 2008a,b). This reflects the expected influence of life history traits on genetic structure (Tarnowska et al. 2012), although it is possible that in some of those species, larger sample sizes and refined data analyses (e.g. using $F_{\mathrm{ST}}$ instead of $\Phi_{\mathrm{ST}}$ ) could reveal other cases of genetic differentiation within region, even for species that dis- perse via a larva. This is supported by our results and by the finding, in the Pacific Ocean, of genetic structure at small distances $(<10 \mathrm{~km})$ in a highly fecund larva-producing echinoderm, the crown-of-thorns starfish (Timmers et al. 2012).

\section{The case of Lebanon}

The second major finding of our study is the differentiation of the population of the Levantine basin, as highlighted by the COI marker, for which the most common haplotype was absent in Lebanon (Figs. 1 \& 2 ), and by high $F_{\mathrm{ST}}$ values (Table $\mathrm{S} 1$ ). The distinction between the easternmost populations and other Mediterranean populations is rarely investigated in marine species. As an example, a Levantine clade has been discovered within the cryptic species complex of the gastropod Dendropoma petraeum, but this species does not present a pelagic larval stage (Calvo et al. 2009), and a separate clade within the Levantine basin is also suspected in the sea bass Dicentrarchus labrax (Castilho \& Ciftci 2005).

A possible explanation for the differentiation of the Lebanese population may involve the low planktonic blooms within the oligotrophic Levantine basin (D'Ortenzio \& Ribera 2008). Larval survival and recruitment in Paracentrotus lividus are highly dependent on spring planktonic blooms (Lopéz et al. 1998). The reduction of this bloom might decrease larval survival time, and thus gene flow in this area. The absence of differentiation with the nuclear marker may be explained by the lower genetic drift affecting nuclear genomes relative to mitochondrial ones (due to effective size differences), causing slower differentiation (Ballard \& Whitlock 2004). An alternative hypothesis assumes that selection on the mitochondrial marker would be responsible for the differentiation observed in the Lebanese sample. Selection was already suggested in a study of stressed populations from Greece (Rizzo et al. 2009). The Lebanese population is located in the region with the most oligotrophic waters in the distribution range of $P$. lividus, as well as the highest mean seawater temperatures. It is possible that natural selection eliminates the larvae containing the very common COI haplotypes found in other populations (including the most common haplotype). A correlation between sea surface temperature and mitochondrial DNA haplotypes was reported for the North Pacific walleye pollock (Grant et al. 2006), and a relation between chlorophyll $a$ concentration and the relative abundance of mitochondrial lineages of an ophiuroid species complex was reported in 
Mediterranean basins (Boissin et al. 2011). This hypothesis implies that a migration load affects these sea urchin populations, with maladapted mitochondrial genotypes being introduced by gene flow (as suggested by nuclear markers) and eliminated continuously by selection.

\section{Position of transition zones and asymmetric gene flow}

At the inter-basin level, the AMOVA tests favor the hypothesis that the transition zone between the Mediterranean and Atlantic population groups occurs within the Alboran Sea, west of the AlmeriaOran front. The transition zone between Adriatic and other Mediterranean populations remains unclear, but is likely to be between the south of the Adriatic Sea and Sicily. Moreover, the multilocus analyses of gene flow under a model of isolation with migration (IM model) unambiguously established the unidirectionality of gene flow from the Atlantic Ocean to the Mediterranean Sea, confirming previous studies which suggested asymmetric gene flow (Calderón et al. 2008, Maltagliati et al. 2010). Strasburg \& Riesberg (2010) demonstrated that population structure within species had little effect on parameter estimates using the IM model, even for fairly high levels of structure. Thus, despite within-basin population structure, the unambiguously asymmetric pattern we found can be considered a robust result. The results of the Bayesian analysis (IMa2) are clearly illustrated by the fact that some frequent haplotypes and even some haplogroups of the COI, Cyt b, and i2 1 markers are not found outside the Mediterranean Sea (Fig. 2). Such asymmetrical gene flow was previously suggested for a cuttlefish (Pérez-Losada et al. 1999), a seabream (Bargelloni et al. 2005), an oyster (Saavedra et al. 1993), and a crustacean (Pannacciulli et al. 1997). Such observations are consistent with the current circulation pattern across the Strait of Gibraltar (Millot 1999), i.e. superficial waters flowing from the Atlantic to the Mediterranean Sea.

We estimated that the Atlantic and Mediterranean Sea populations diverged from an ancestral population between 0.27 and 0.3 Myr ago, depending on the mutation rate considered. This places the divergence after the transition during the middle Pleistocene that started between 0.7 and $0.8 \mathrm{Myr}$ ago. This period corresponds to an increase in long-term global ice volume and a strong reduction of the North Atlantic thermohaline circulation that influenced global oceanic circulation (Head et al. 2008). Cycles of climate fluctuation starting from the transition between early and middle Pleistocene were characterized by more severe glaciations, which may have initiated the differentiation between Atlantic and Mediterranean populations (Almogi-Labin 2011). However, we may have underestimated the substitution rate of our markers, due to calibration using an old divergence time, and thus overestimated divergence times (e.g. Crandall et al. 2012). This would strengthen the conclusion that the 'Atlanto-Mediterranean' divergence and the demographic expansion did not predate the middle Pleistocene. The differentiation between Mediterranean and Atlantic basins may have been maintained because of hydrographic barriers to dispersal, differential selective pressures or the evolution of mechanisms of reproductive isolation (Bierne et al. 2011). Nevertheless, the Quaternary sea level and sea temperature fluctuations do not appear to have strongly reduced the genetic diversity of this species, which appears to have undergone demographic expansions much before the last glaciation for both the Atlantic and the Mediterranean basins (always more, sometimes much more, than 100000 yr ago for all basins and all markers, Penant 2012). This observation is in line with the present distribution of Paracentrotus lividus, which may be observed as far north as the Irish coasts. $P$. lividus populations likely persisted in the Mediterranean Sea and in the southern part of the North Atlantic during glacial events, as sea surface temperatures for the Mediterranean during the Last Glacial Maximum (LGM) were estimated at around $7{ }^{\circ} \mathrm{C}$ in winter and 9 to $13^{\circ} \mathrm{C}$ in summer (Thiede 1978 , Hayes et al. 2005). Published studies analyzing models of isolation with migration between the Atlantic and Mediterranean basins are not common, but many studies estimated divergence times between pairs of Atlantic and Mediterranean sister species, finding both pre-Messinian (Sotelo et al. 2009, Xavier et al. 2012) and post-Messinian events (Luttikhuizen et al. 2008, Egea 2011). Population expansion times are more often estimated (Patarnello et al. 2007), giving expansions as recent as the LGM (Palero et al. 2008) to expansions older than $500000 \mathrm{yr}$, most of them being between 50000 and 200000 yr. P lividus thus appears in the range of divergence and expansion times inferred for other Atlanto-Mediterranean taxa.

\section{CONCLUSIONS}

Beyond its paradoxical nature and fundamental interest, our finding that genetic differentiation 
within regions is the rule in the bentho-pelagic sea urchin Paracentrotus lividus raises important questions for the management of this exploited species. The local depletions reported by fishermen on the French Mediterranean coast where this species is traditionally consumed may be explained by limited gene flow among localities; moreover, replenishment from migrants appears less likely than previously thought, and the sustainability of this level of harvesting may become an issue. Determining whether population differentiation is due to limited dispersal or to local adaptation will be the next step. The use of more nuclear markers should help to separate demographic and selective components in the observed patterns of genetic structure (within regions, and also to test whether the discrepancy observed for Lebanon between i2 1 and COI is due to stochasticity or to selection). Experimental approaches or methods based on genome scanning may help to detect local adaptation.

Acknowledgements. We thank E. Egea, K. Gérard, C. Abed, F. Zuberer, J. Garrabou, and J. Vierna who kindly provided specimens for this work. This work is part of G.P.'s PhD thesis funded by Région Proven ce-Alpes-Côte-d'Azur.

\section{LITERATURE CITED}

Almogi-Labin A (2011) The paleoclimate of the eastern Mediterranean during the transition from early to mid pleistocene (900 to $700 \mathrm{ka}$ ) based on marine and nonmarine records: an integrated overview. J Hum Evol 60: $428-436$

Arculeo M, Lo Brutto S, Pancucci MP, Cammarata M, Parrinello N (1998) Allozyme similarity in two morphologically distinguishable populations of Paracentrotus lividus (Echinodermata) from distinct areas of the Mediterranean coast. J Mar Biol Assoc UK 78:231-238

Arnaud Haond S, Migliaccio M, Diaz Almela E, Teixeira S and others (2007) Vicariance patterns in the Mediterranean Sea: east-west cleavage and low dispersal in the endemic seagrass Posidonia oceanica. J Biogeogr 34: 963-976

Arndt A, Marquez C, Lambert P, Smith MJ (1996) Molecular phylogeny of eastern Pacific sea cucumbers (Echinodermata: Holothuroidea) based on mitochondrial DNA sequence. Mol Phylogenet Evol 6:425-437

Aurelle D, Ledoux JB, Rocher C, Borsa P, Chenuil A, Feral JP (2011) Phylogeography of the red coral (Corallium rubrum): inferences on the evolutionary history of a temperate gorgonian. Genetica 139:855-869

Avise JC (1998) Conservation genetics in the marine realm. JHered 89:377-382

Avise JC (2000) Phylogeography: the history and formation of species. Harvard University Press, Cambridge, MA

Bahri-Sfar L, Lemaire C, Hassine OKB, Bonhomme F (2000) Fragmentation of sea bass populations in the western and eastern Mediterranean as revealed by microsatellite polymorphism. Proc R Soc Lond B Biol Sci 267:929-935

Ballard JWO, Whitlock MC (2004) The incomplete natural history of mitochondria. Mol Ecol 13:729-744

Bargelloni L, Alarcon J, Alvarez M, Penzo E, Magoulas A, Palma J, Patarnello T (2005) The Atlantic-Mediterranean transition: discordant genetic patterns in two seabream species, Diplodus puntazzo (Cetti) and Diplodus sargus (L.). Mol Phylogenet Evol 36:523-535

Baus E, Darrock DJ, Bruford MW (2005) Gene-flow patterns in Atlantic and Mediterranean populations of the Lusitanian sea star Asterina gibbosa. Mol Ecol 14:3373-3382

Benjamini Y, Hochberg Y (1995) Controlling the false discovery rate: a practical and powerful approach to multiple testing. J R Stat Soc B 57:289-300

Bierne N, Welch J, Loire E, Bonhomme F, David P (2011) The coupling hypothesis: why genome scans may fail to map local adaptation genes. Mol Ecol 20:2044-2072

Boissin E, Feral JP, Chenuil A (2008a) Defining reproductively isolated units in a cryptic and syntopic species complex using mitochondrial and nuclear markers: the brooding brittle star, Amphipholis squamata (Ophiuroidea). Mol Ecol 17:1732-1744

Boissin E, Hoareau TB, Féral JP, Chenuil A (2008b) Extreme selfing rates in the cosmopolitan brittle star species complex Amphipholis squamata: data from progeny-array and heterozygote deficiency. Mar Ecol Prog Ser 361: 151-159

Boissin E, Stöhr S, Chenuil A (2011) Did vicariance and adaptation drive cryptic speciation and evolution of brooding in Ophioderma longicauda (Echinodermata: Ophiuroidea), a common Atlanto-Mediterranean ophiuroid? MolEcol20:4737-4755

Borrero-Pérez GH, González-Wanguemert M, Marcos C, Pérez-Ruzafa A (2011) Phylogeography of the AtlantoMediterranean sea cucumber Holothuria (Holothuria) mammata: the combined effects of historical processes and current oceanographical pattern. Mol Ecol 20: 1964-1975

Borsa P, Naciri M, Bahri L, Chikhi L, Garcia De Leon FJ, Kotoulas G, Bonhomme F (1997a) Infraspecific zoogeography of the Mediterranean: population genetic analysis on sixteen Atlanto-Mediterranean species (fishes and invertebrates). Vie Milieu 47:295-305

Borsa P, Blanquer A, Berrebi P (1997b) Genetic structure of the flounders Platichthys flesus and P. stellatus at different geographic scales. Mar Biol 129:233-246

Boudouresque CF, Verlaque M (2007) Ecology of Paracentrotus lividus. In: Lawrence JM (ed) Edible sea urchins: biology and ecology. Elsevier, Amsterdam, p 243-286

Calderón I, Turon X (2010) Temporal genetic variability in the Mediterranean common sea urchin Paracentrotus lividus. Mar Ecol Prog Ser 408:149-159

Calderón I, Giribet G, Turon X (2008) Two markers and one history: phylogeography of the edible common sea urchin Paracentrotus lividus in the Lusitanian region. Mar Biol 154:137-151

Calderón I, Palacìn C, Turon X (2009a) Microsatellite mar- kers reveal shallow genetic differentiation between co- horts of the common sea urchin Paracentrotus lividus (Lamarck) in northwest Mediterranean. Mol Ecol 18: 3036-3049

Calderón I, Turon X, Lessios HA (2009b) Characterization of the sperm molecule bindin in the sea urchin genus Paracentrotus. J Mol Evol 68:366-376

Calderón I, Pita L, Brusciotti S, Palacin C, Turon X (2012) 
Time and space: genetic structure of the cohorts of the common sea urchin Paracentrotus lividus in Western Mediterranean. Mar Biol 159:187-197

Calvo M, Templado J, Oliverio M, Machordom A (2009) Hidden Mediterranean biodiversity: molecular evidence for a cryptic species complex within the reef building vermetid gastropod Dendropoma petraeum (Mollusca: Caenogastropoda). Biol J Linn Soc 96:898-912

Castilho R, Ciftci Y (2005) Genetic differentiation between close eastern Mediterranean Dicentrarchus labrax (L.) populations. J Fish Biol 67:1746-1752

Chaoui L, Kara MH, Quignard JP, Faure E, Bonhomme F (2009) Forte différenciation génétique de la daurade Sparus aurata (L., 1758) entre les deux rives de la Méditerranée occidentale. C R Biol 332:329-335

Chatti N, Zitari-Chatti R, Attia MH, Ben Khadra Y, Said K (2012) Very low mitochondrial diversity and genetic homogeneity in the starfish Echinaster sepositus along the Tunisian coast. Biochem Genet 50:45-51

Chenuil A, Egea E, Rocher C, Touzet H, Feral JP (2008) Does hybridization increase evolutionary rate? Data from the 28S-rDNA D8 domain in echinoderms. J Mol Evol 67: $539-550$

Chenuil A, Hoareau TB, Egea E, Penant G and others (2010) An efficient method to find potentially universal popula- tion genetic markers, applied to metazoans. BMC Evol Biol 10:276

Clement M, Posada D, Crandall KA (2000) TCS: a computer program to estimate gene genealogies. Mol Ecol 9: 1657-1659

Coll M, Piroddi C, Steenbeek J, Kaschner K and others (2010) The biodiversity of the Mediterranean Sea: estimates, patterns, and threats. PLoS ONE 5:e11842

Crandall ED, Sbrocco EJ, DeBoer TS, Barber PH, Carpenter KE (2012) Expansion dating: calibrating molecular clocks in marine species from expansions onto the Sunda Shelf following the Last Glacial Maximum. Mol Biol Evol 29: 707-719

D'Ortenzio F, Ribera DA (2008) On the trophic regimes of the Mediterranean Sea: a satellite analysis. Biogeosci Discuss 5:2959-2983

Domingues VS, Bucciarelli G, Almada VC, Bernardi G (2005) Historical colonization and demography of the Mediterranean damselfish, Chromis chromis. Mol Ecol 14:4051-4063

Drummond AJ, Rambaut A (2007) Beast: Bayesian evolutionary analysis by sampling trees. BMC Evol Biol 7:214

Duran S, Palacin C, Becerro MA, Turon X, Giribet G (2004) Genetic diversity and population structure of the commercially harvested sea urchin Paracentrotus lividus (Echinodermata: Echinoidea). MolEcol 13:3317-3328

Egea E (2011) Histoire évolutive, structures génétique, morphologique et écologique comparées dans un complexe d'espèces jumelles: Echinocardium cordatum (Echinoidea, Irregularia). PhD thesis, Aix-Marseille Université, Marseille

Excoffier L, Lischer HEL (2010) Arlequin suite ver 3.5: a new series of programs to perform population genetics analyses under Linux and Windows. Mol Ecol Resour 10: 564-567

Excoffier L, Smouse PE, Quattro JM (1992) Analysis of molecular variance inferred from metric distances among DNA haplotypes: application to human mitochondrialDNA restriction data. Genetics 131:479-491

Fu YX (1997) Statistical tests of neutrality of mutations against population growth, hitchhiking and background selection. Genetics 147:915-925

Galtier N, Nabholz B, Glemin S, Hurst G (2009) Mitochondrial DNA as a marker of molecular diversity: a reappraisal. MolEcol 18:4541-4550

Grant WS, Spies IB, Canino MF (2006) Biogeographic evidence for selection on mitochondrial DNA in North Pacific walleye pollock Theragra chalcogramma. J Hered 97:571-580

Guidetti P (2006) Marine reserves reestablish lost predatory interactions and cause community changes in rocky reefs. Ecol Appl 16:963-976

Hasegawa M, Kishino H, Yano T (1985) Dating of the humanape splitting by a molecular clock of mitochondrial DNA. J Mol Evol 22:160-174

Hayes A, Kucera M, Kallel N, Sbaffi L, Rohling EJ (2005) Glacial Mediterranean Sea surface temperatures based on planktonic foraminiferal assemblages. Quat Sci Rev 24:999-1016

Head MJ, Pillans B, Farquhar SA (2008) The Early-Middle Pleistocene Transition: characterization and proposed guide for the defining boundary. Episodes 31:255-259

Hey J (2010) Isolation with migration models for more than two populations. Mol Biol Evol 27:905

Hudson RR, Turelli M (2003) Stochasticity overrules the 'three-times rule': genetic drift, genetic draft, and coalescence times for nuclear loci versus mitochondrial DNA. Evolution 57:182-190

Iuri V, Patti F, Procaccini G (2007) Phylogeography of the sea urchin Paracentrotus lividus (Lamarck) (Echinodermata: Echinoidea): first insights from the south Tyrrhenian Sea. In: Relini G, Ryland J (eds) Biodiversity in enclosed seas and artificial marine habitats. Springer, Dordrecht, p77-84

Johnson MS, Black R (1984) Pattern beneath the chaos: the effect of recruitment on genetic patchiness in an intertidal limpet. Evolution 38:1371-1383

Lessios HA, Kessing B, Robertson DR, Paulay G (1999) Phylogeography of the pantropical sea urchin Eucidaris in relation to land barriers and ocean currents. Evolution 53:806-817

Librado P, Rozas J (2009) DnaSP v5: a software for comprehensive analysis of DNA polymorphism data. Bioinformatics 25:1451

Lopéz S, Turon X, Montero E, Palacín C, Duarte CM, Tarjuelo I (1998) Larval abundance, recruitment and early mortality in Paracentrotus lividus (Echinoidea). Interannual variability and plankton-benthos coupling. Mar Ecol Prog Ser 172:239-251

Louise F, Benard F (1993) Déterminisme génétique du polychromatisme de Paracentrotus lividus (Lamarck) [Genetic determination of polychromatism of Paracentrotus lividus (Lamarck)]. Bull Soc Zool Fr 118:405-408 (in French with English Abstract)

Louise F, Benard F (1995a) Déterminisme génétique de la costulation des piquants de Paracentrotus lividus (Lamarck): première observation [Genetic determination in costulation of spines of Paracentrotus lividus (Lamarck): first observation]. Bull Soc Zool Fr 120:57-60 (in French with English Abstract)

Louise F, Benard F (1995b) Déterminisme génétique du polychromatisme de Paracentrotus lividus (Lamarck). II: Etude préliminaire de quelques phénotypes colorés [Genetic determination in polychromatism of Paracentrotus lividus (Lamarck). II: Preliminary study of several 
coloured phenotypes]. Bull Soc Zool Fr 120:61-64 (in French with English Abstract)

Lozano J, Galera J, López S, Turon X, Palacín C, Morera G (1995) Biological cycles and recruitment of Paracentrotus lividus (Echinodermata: Echinoidea) in two contrasting habitats. Mar Ecol Prog Ser 122:179-191

Luttikhuizen PC, Campos J, van Bleijswijk J, Peijnenburg K, van der Veer HW (2008) Phylogeography of the common shrimp, Crangon crangon (L.) across its distribution range. Mol Phylogenet Evol 46:1015-1030

Maggio T, Lo Brutto S, Garoia F, Tinti F, Arculeo M (2009) Microsatellite analysis of red mullet Mullus barbatus (Perciformes, Mullidae) reveals the isolation of the Adriatic basin in the Mediterranean Sea. ICES J Mar Sci 66: 1883-1891

Magoulas A, Castilho R, Caetano S, Marcato S, Patarnello T (2006) Mitochondrial DNA reveals a mosaic pattern of phylogeographical structure in Atlantic and Mediterranean populations of anchovy (Engraulis encrasicolus). Mol Phylogenet Evol39:734-746

Maltagliati F, Di Giuseppe G, Barbieri M, Castelli A, Dini F (2010) Phylogeography and genetic structure of the edible sea urchin Paracentrotus lividus (Echinodermata: Echinoidea) inferred from the mitochondrial cytochrome $b$ gene. Biol J Linn Soc 100:910-923

McCartney MA, Keller G, Lessios HA (2000) Dispersal barriers in tropical oceans and speciation in Atlantic and eastern Pacific sea urchins of the genus Echinometra. MolEcol9:1391-1400

Micheli F, Benedetti-Cecchi L, Gambaccini S, Bertocci I, Borsini C, Chato Osio G, Romano F (2005) Cascading human impacts, marine protected areas, and the structure of Mediterranean reef assemblages. Ecol Monogr 75:81-102

Millot C (1999) Circulation in the Western Mediterranean Sea. J Mar Syst 20:423-442

Muller K (2005) SeqState: Primer design and sequence statistics for phylogenetic DNA datasets. Appl Bioinform 4: 35-69

Nielsen R, Wakeley J (2001) Distinguishing migration from isolation: a Markov chain Monte Carlo approach. Genetics 158:885-896

Palero F, Abello P, Macpherson E, Gristina M, Pascual M (2008) Phylogeography of the European spiny lobster (Palinurus elephas): influence of current oceanographical features and historical processes. Mol Phylogenet Evol 48:708-717

Pannacciulli F, Bishop J, Hawkins S (1997) Genetic structure of populations of two species of Chthamalus (Crustacea: Cirripedia) in the north-east Atlantic and Mediterranean. MarBiol 128:73-82

Patarnello T, Volckaert F, Castilho R (2007) Pillars of Hercules: Is the Atlantic-Mediterranean transition a phylogeographical break? Mol Ecol 16:4426-4444

Pedrotti M (1993) Spatial and temporal distribution and recruitment of echinoderm larvae in the Ligurian Sea. J Mar Biol Assoc UK 73:513-530

Peijnenburg KTCA, Fauvelot C, Breeuwer AJ, Menken SBJ (2006) Spatial and temporal genetic structure of the planktonic Sagitta setosa (Chaetognatha) in European seas as revealed by mitochondrial and nuclear DNA markers. MolEcol 15:3319-3338

Penant G (2012) Structure génétique et dispersion en milieu marin: le cas de l'oursin commun Paracentrotus lividus et du sar commun Diplodus sargus. $\mathrm{PhD}$ thesis,
Aix-Marseille Université, Marseille

Pérez-Losada M, Guerra A, Sanjuan A (1999) Allozyme differentiation in the cuttlefish Sepia officinalis (Mollusca: Cephalopoda) from the NE Atlantic and Mediterranean. Heredity 83:280-289

Petit RJ, El Mousadik A, Pons O (1998) Identifying popula- tions for conservation on the basis of genetic markers. Conserv Biol 12:844-855

Pinnegar JK, Polunin NVC, Francour P, Badalamenti F and others (2000) Trophic cascades in benthic marine ecosystems: lessons for fisheries and protected area management. Environ Conserv 27:179-200

Posada D (2008) jModelTest: phylogenetic model averaging. Mol Biol Evol 25:1253

Ramos-Onsins SE, Rozas J (2002) Statistical properties of new neutrality tests against population growth. Mol Biol Evol 19:2092

Raymond M, Rousset F (1995) Genepop (version 1.2) - Population genetics software for exact tests and ecumenism. J Hered 86:246-249

Rizzo C, Cammarata M, Di Carlo M, Pancucci A, Parrinello N (2009) RAPD profiles distinguish Paracentrotus lividus populations living in a stressing environment (Amvrakikos Gulf, Greece). Russ J Genet 45:499-503

Ruzzante DE, Mariani S, Bekkevold D, Andre C and others (2006) Biocomplexity in a highly migratory pelagic marine fish, Atlantic herring. Proc R Soc Lond B Biol Sci 273: 1459-1464

Ryman N, Palm S (2006) POWSIM: a computer program for assessing statistical power when testing for genetic differentiation. Mol Ecol Notes 6:600-602

Ryman N, Palm S, Andre C, Carvalho GR and others (2006) Power for detecting genetic divergence: differences between statistical methods and marker loci. Mol Ecol 15:2031-2045

Saavedra C, Zapata C, Guerra A, Alvarez G (1993) Allozyme variation in European populations of the oyster Ostrea edulis. Mar Biol 115:85-95

Sala E, Ribes M, Hereu B, Zabala M, Alvà V, Coma R, Garrabou J (1998) Temporal variability in abundance of the sea urchins Paracentrotus lividus and Arbacia lixula in the northwestern Mediterranean: comparison between a marine reserve and an unprotected area. Mar Ecol Prog Ser 168:135-145

Sellem F, Guillou M (2007) Reproductive biology of Paracentrotus lividus (Echinodermata: Echinoidea) in two contrasting habitats of northern Tunisia (south-east Mediterranean). J Mar Biol Assoc UK 87:763-767

Siegel D, Mitarai S, Costello C, Gaines S, Kendall B, Warner R, Winters K (2008) The stochastic nature of larval connectivity among nearshore marine populations. Proc Natl Acad Sci USA 105:8974

Smith AB, Pisani D, Mackenzie-Dodds JA, Stockley B, Webster BL, Littlewood DTJ (2006) Testing the molecular clock: molecular and paleontological estimates of divergence times in the Echinoidea (Echinodermata). Mol Biol Evol 23:1832-1851

So JJ, Uthicke S, Hamel JF, Mercier A (2011) Genetic population structure in a commercial marine invertebrate with long-lived lecithotrophic larvae: Cucumaria frondosa (Echinodermata: Holothuroidea). Mar Biol 158:859-870

Sotelo G, Moran P, Posada D (2009) Molecular phylogeny and biogeographic history of the European Maja spider crabs (Decapoda, Majidae). Mol Phylogenet Evol 53: 314-319 
Strasburg JL, Riesberg LH (2010) How robust are 'isolation with migration' analyses to violations of the IM model? A simulation study. Mol Biol Evol 27:297-310

Tajima F (1989) Statistical method for testing the neutral mutation hypothesis by DNA polymorphism. Genetics 123:585-595

Tarnowska K, Chenuil A, Nikula R, Féral JP, Wolowicz M (2010) Complex genetic population structure of the bivalve Cerastoderma glaucum in a highly fragmented lagoon habitat. Mar Ecol Prog Ser 406:173-184

Tarnowska K, Krakau M, Jacobsen S, Wolowicz M, Féral JP, Chenuil A (2012) Comparative phylogeography of two sister (congeneric) species of cardiid bivalve: strong influence of habitat, life history and post-glacial history. EstuarCoast ShelfSci 107:150-158

Thiede J (1978) A glacial Mediterranean. Nature 276: 680-683 Timmers MA, Bird CE, Skillings DJ, Smouse PE, Toonen RJ (2012) There's no place like home: crown-of-thorns outbreaks in the central Pacific are regionally derived and independent events. PLoS ONE 7:e31159
Weersing K, Toonen RJ (2009) Population genetics, larval dispersal, and connectivity in marine systems. Mar Ecol Prog Ser 393:1-12

Weir B, Cockerham CC (1984) Estimating F-statistics for the analysis of population structure. Evolution 38: $1358-1370$

Xavier R, Santos AM, Harris DJ, Sezgin M, Machado M, Branco M (2012) Phylogenetic analysis of the northeast Atlantic and Mediterranean species of the genus Stenosoma (Isopoda, Valvifera, Idoteidae). Zool Scr 41: 386-399

Zitari-Chatti R, Chatti N, Fulgione D, Caiazza I and others (2009) Mitochondrial DNA variation in the caramote prawn Penaeus (Melicertus) kerathurus across a transition zone in the Mediterranean Sea. Genetica 136: 439-447

Zulliger DE, Tanner S, Ruch M, Ribi G (2009) Genetic struc- ture of the high dispersal Atlanto-Mediterreanean sea star Astropecten aranciacus revealed by mitochondrial DNA sequences and microsatellite loci. Mar Biol 156: 597-610 